\title{
二方向地震入力を受ける球面すべり支承および上部構造の応答特性 \\ RESPONSE CHARACTERISTICS OF SPHERICAL SLIDING BEARINGS AND SUPERSTRUCTURE SUBJECT TO BIDIRECTIONAL GROUND MOTIONS
}

\author{
竹内 徹*1, 内田正颯*2, 松井良太范
}

Toru TAKEUCHI, Masakaze UCHIDA and Ryota MATSUI

\begin{abstract}
Although the performance of seismic isolation devices as rubber bearings or dampers have been tested and evaluated through unidirectional input, actual seismic response working on these devices are bidirectional. Recently the performance of high-damping rubber bearings is found to be different from those under unidirectional input, and bidirectional tests for various isolation devices are being carried out. In this paper, bidirectional shaking table tests for SSB (Spherical Sliding B earing/ Friction Pendulum B earing: FPB) are carried out, and the difference of their response against unidirectional response is researched. Found bidirectional effects are discussed using analytical model taking these effects into account, followed by the studies on the effects on the response of supported superstructures.
\end{abstract}

Keywords : Spherical Sliding Bearing, Bidirectional Ground Motions, Seismic Isolation, Response Characteristics 球面す心゙り支承，二方向地震入力，免震構造，応答特性

\section{1. 序}

従来, 免震構造に用いられる各種の免震装置は水平一方向加力試 験によりその性能の確認が行われ，その履歴特性が設計に利用され てきた。現実には地震時に免震装置には水平二方向応答が発生し, このような応答に対する二方向同時加力実験を行った際に一方向加 力とは異なる特性を示す免震装置があることが指摘され，近年多種 の免震装置に対し水平二方向加力下での性能確認が求められるよう になってきている。嶺脇ら ${ }^{1)}$ は高減衰ゴム系積層ゴム実大部材を用 いた水平二方向加力実験において, 加力方向に直交する方向に特異 な履歴が現れることや，一方向加力試験に基づいて定められた限界 水平変形の基準值を下回る変形で破断が生じた試験体があったこと から，水平一方向加力試験より得られる知見の限界を指摘した。以 降, 菊地ら ${ }^{21}$ や鴨下ら ${ }^{31}$ により積層ゴム支承や寸べり支承など種々 の免震部材の水平二方向加力試験が行われ，二方向加力による降伏 後の剛性低下や履歴形状の変化等, 水平二方向応答の特性が報告さ れ，これらを表現できる力学モデルが提案されている ${ }^{4)}$ 。一方，近 年日本においても適用が始まった球面す心゙り支承 (Friction Pendulum B earing: FPB / Spherical Sliding B earing: SSB) に関して，上 記のような研究を行った例は殆ど見られない。

SSB は表面をテフロン系の材料で加工したスライダーをステンレ ス球面間に挟んで配置したす心゙り型免震支承であり，摩擦力による
履歴減衰機構と振り子運動による復元機構を有する。筆者ら ${ }^{6)}$ は SSB 付架構の一方向縮小振動台実験を行い, 他のテフロン系すべり 支承之同様 SSB が面圧依存性や速度依存性を有寸る点や, 支持架構 の重量が偏心する場合にも捩れ応答の増幅があまり見られないこと を示した。また，支承部で浮き上がりが生じた場合にも，残留変形 にやや影響がある一方で水平応答には影響が殆どないことを示した。 SSB はす心゙り支承の一種であるため, 水平二方向の履歴モデルに関 しては鴨下ら ${ }^{31}$ のすべり支承モデルが応用可能と考えられる。しか し振り子運動が与える復元力特性や鉛直振動が上部構造に与える影 響についてはまだ不明な点が多い。

本研究では, SSB を用いた水平二方向振動台実験を実施し, 水平 二方向応答特性を調查する。設計用地震波を各方向で独立に一方向 入力した場合と，二方向同時入力した場合の各方向の免震層および 上部構造の応答特性を比較することで，二方向同時入力時の応答が 一方向入力時の応答評価に対し与える影響について着目した検討を 行う。加えて, 文献 7) で構築した振り子運動を含む SSB の力学モ デルであるFP モデルを用いて実験の再現解析を試み, 同モデルが SSB の二方向応答を再現し得るか検証する。また，SSB で支持され た重層倉庫を想定した立体架構を用いて一方向および二方向入力に よる時刻歴応答解析を行い, SSB の二方向応答が上部構造へ与える 影響を検証する。
*1 東京工業大学建築学系 教授 · 博士 (工学)

*2 元 東京工業大学建築学専攻 大学院生・修士(工学)

*3 東京工業大学建築学系 助教・博士 (工学)
Prof., Dept. of Arch. and Build. Eng., Tokyo Institute of Technology, Dr. Eng. Former Grad. Student, Dept. of Arch. and Build. Eng., Tokyo Institute of Technology, M. Eng. Assist. Prof., Dept. of Arch. and Build. Eng., Tokyo Institute of Technology, Dr. Eng. 
2. SSB の水平二方向振動台実験

SSB の水平二方向応答特性を検証するため振動台実験を行う。既 往の二方向免震装置応答研究 21,5 等では, 各方向のエネルギー入力を一 定として比較するため、入力方向に応じて方向余弦を乗じる等の処置 を行い，免震装置としての二方向特性を議論することが多い。一方， 上部構造物の耐震設計では架構の直交各方向における応答の独立性 を前提に, $x$, y 方向で独立に耐震設計を実施することが一般的である。 本研究では汎用的に設計で用いられる二方向観測波を各方向で独立 に一方向入力した場合と，二方向同時入力した場合の各方向の上部構 造の応答特性を直接比較することで，二方向同時入力時の応答が一 方向入力時の応答評価に対し与える影響に着目した検討を行う。

\section{1 試験体概要}

Fig.1 に本実験に用いる SSB を示す。すべり面は汎用的に用いら れるサイズの約 $1 / 3$ の径とし, 基準面圧 $\left(60 \mathrm{~N} / \mathrm{mm}^{2}\right)$ における速度 $400 \mathrm{~mm} / \mathrm{s}$ での基準摩擦係数は 0.047 とする ${ }^{10)}$ 。スライダー径は $\phi=30 \mathrm{~mm}$, すべり面の球面半径は $\mathrm{I}=2.5 \mathrm{~m}$ とする。固有周期は式 (1) よ り実大と同様の約 $4.5 \mathrm{~s}$ とし, 可動振幅以外の特性を実大と合わせる。 ここに $g:$ 重力加速度である。

$$
\mathrm{T}=2 \pi \sqrt{\frac{21}{g}}=4.49 \text { (s) }
$$

\section{2 振動台実験概要}

Fig.2 に振動台実験セットアップ図を各種測定位置と合わせて示 す。錘 $(78 \mathrm{~kg} /$ 枚) 20 枚は錘積載治具(0.2t)を介して SSB に計 $1.76 \mathrm{t}$ を 積載する。ボールベアリングは振動台から約 $2 \mathrm{~mm}$ 浮いており, SSB のみで荷重を支持させるため, スライダー面圧は約 $24.3 \mathrm{~N} / \mathrm{mm}^{2}$ とな る。この時, 文献 6) に示される式 (2) よりSSB の摩擦係数は速度 $\mathrm{v}=400 \mathrm{~mm} / \mathrm{s}$ で $\mu=0.056$ 程度となる。

$$
\mu=\mu_{0} \times\left(1.746 \sigma^{-0.141}+0.02\right) \times\left(1-0.55 \mathrm{e}^{-0.019 \mathrm{v}}\right) \times \mathrm{e}^{\left(20+\mathrm{v}^{0.4}\right) / \sigma^{2}}
$$

ここに, $\mu$ : 摩擦係数, $\mu_{0}$ : 基準摩擦係数, $\sigma$ : スライダー面圧 $\left(\mathrm{N} / \mathrm{mm}^{2}\right)$ である。

支承部せん断力測定のため, 摩擦係数が約 1/1000 と十分に小さい 転がり支承 (SBB) でSSB を支持した上で, 歪ゲージを貼付した口 ードセルを介して SSB 下部コンケイブプレートを振動台と固定す る。また, レーザー変位計および加速度計を用いて錘積載治具と振 動台の水平変位および加速度を測定する。

Tablel に入力地震波を示す。振動台は加速度制御である。入力に は，観測地震波 NS, EW の位相およびレベル 2 の水平動基準応答ス ペクトル ${ }^{11)}$ を用いて作成した地震波計 6 波を用いる。継続時間は 40 s とし，時間軸は原波そのままで，入力レベルは振動台の X 軸方 向にNS 波を，Y 軸方向に $\mathrm{EW}$ 波を入力したときの速度合成べクト ルの最大值が $700 \mathrm{~mm} / \mathrm{s}$ となるよう各方向同等の倍率を乗じて減じ, 縮小モデル用地震波を作成する。以降，NS または EW 方向成分を それぞれ $X, Y$ 一方向入力, 両成分を同時に加えるものを二方向入 力とし, それぞれ 2 回ずつ振動台実験を行う。従って, 二方向入力 時の入力レベルは菊地ら ${ }^{2)}$ の各入力に方向余弦を乗じ入力エネルギ 一を揃えた載荷法に比べ, $\sqrt{2}$ 倍となる。

Fig.3にEL Centro-N 入力で得られた SSB 水平応答変位オービット を示寸。 $X, Y$ それぞれの方向について，「1D-X」「1D-Y」で示寸一方 向入力より「2D」で示寸二方向入力の方が大きく変位している。Fig.4
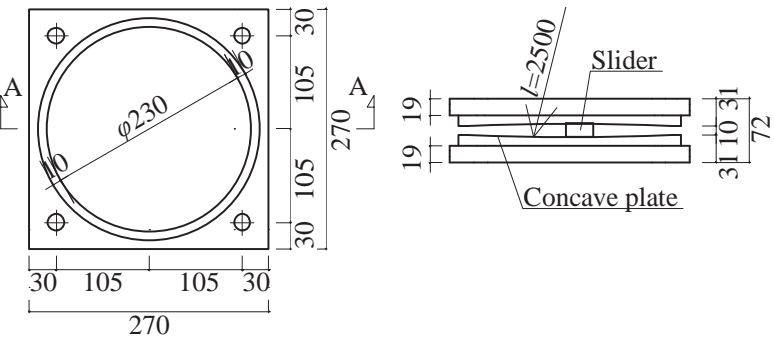

(a) Plan

(b) Section A-A

Fig.1 Composition of SSB
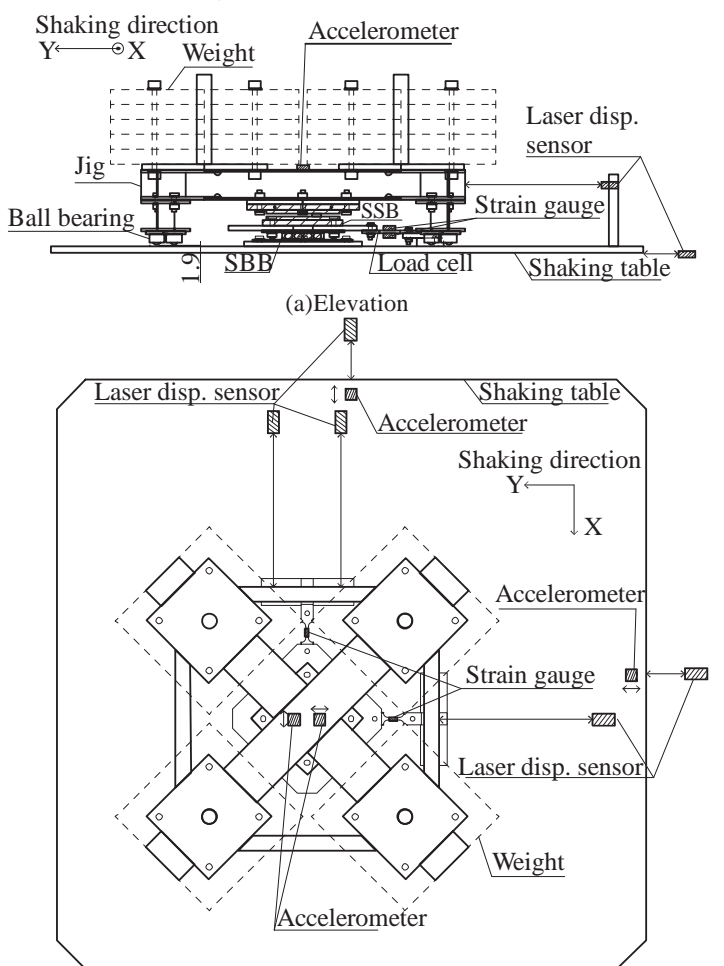

(b) Plan

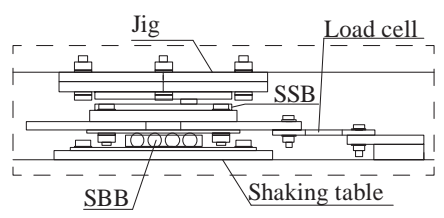

(c) Elevation detail

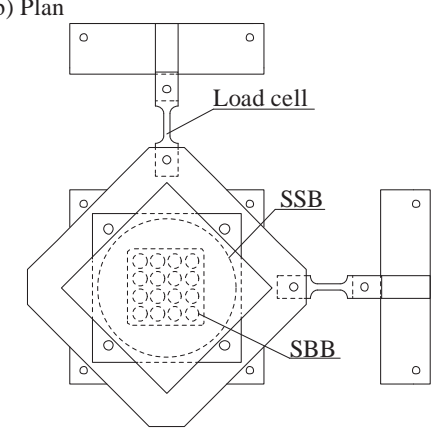

(d) Plan detail under jig

\begin{tabular}{|c|c|c|c|c|c|c|}
\hline W ave name & \multicolumn{2}{|c|}{ EI Centro- $\mathrm{N}$} & \multicolumn{2}{|c|}{ Hachinohe-N } & \multicolumn{2}{|c|}{ JMA Kobe-N } \\
\hline $\begin{array}{l}\text { Acc. orbit } \\
\left(\mathrm{m} / \mathrm{s}^{2}\right)\end{array}$ & -3 & $\begin{array}{l}\left(\mathrm{m} / \mathrm{s}^{2}\right) \\
\sum^{3}\left(\mathrm{~m} / \mathrm{s}^{2}\right)\end{array}$ & & $\left(m / s^{2}\right)$ & & \\
\hline Direction & $N S(X)$ & EW $(Y)$ & NS $(X)$ & EW $(Y)$ & NS $(X)$ & $E W(Y)$ \\
\hline PGA $\left(m / s^{2}\right)$ & 2.32 & 1.84 & 2.67 & 2.07 & 2.78 & 2.51 \\
\hline $\mathrm{PGV}(\mathrm{mm} / \mathrm{s})$ & 529 & 564 & 699 & 398 & 549 & 556 \\
\hline
\end{tabular}

Fig. 2 Tests setup and general instrumentation 
に EL Centro-N 入力の SSB 水平加速度オービットを示寸。一方向入 力と二方向入力で最大応答加速度は殆ど同等であり, 入力方向によ らず入力に対する応答低減が見られる。Fig.5 に ELCentro-N 2D 各方 向のせん断力ー変位関係を示す。既往の研究 ${ }^{3)}$ に示されるすべり支 承と同様，一方向入力に比べて二方向入力ではやや丸みを帯びた履 歴形状に変化する傾向にある。これはスライダーが一度滑り出すと 摩擦力が $X, Y$ 各方向に分力化されるためである。

Fig.6に各 2 回の実験で得られた応答变位と応答加速度の最大值を 組み合わせ，入力方向で比較し示寸。(a)に見るように一方向入力 よりも最大で 2 倍程度大きくなり, その一方で最大応答加速度は(b) に見るように土15\%程度の差に留まり概数各方向の独立性を保つ。最 大方向の入力倍率をエネルギー量で補正した場合でも，変位は二方 向入力でやや大きくなり, 加速度は逆に減少傾向にあると考えられ る。

以上のように, SSB の二方向入力に対する支承部応答において, 入力エネルギーが増大しても応答変位は増大寸る一方で応答加速度 の最大值は一方向入力と同程度となることがわかる。この原因には, すべり機構は滑り出すと全方向に滑り状態となり，二方向連成によ り履歴ループの角が丸くなる特性が寄与していると推察される。

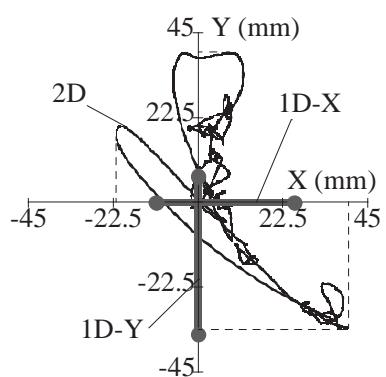

Fig. 3 Horizontal disp. orbit

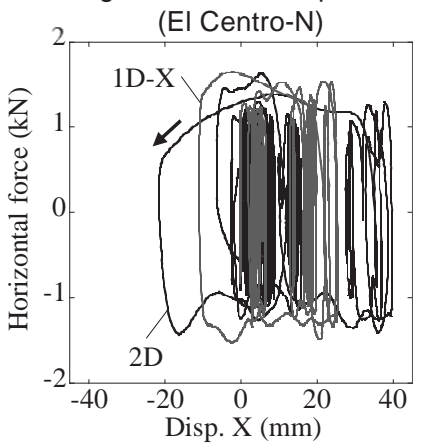

(a) $X$ direction

Fig. 5 Horizontal force -

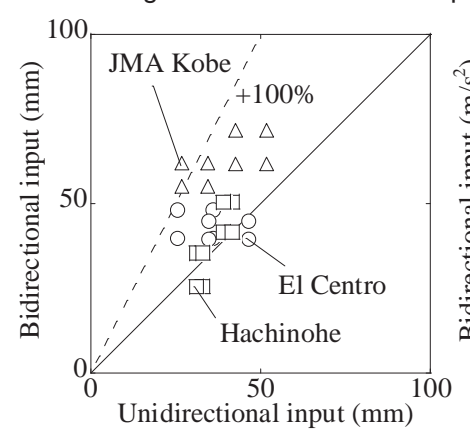

(a) Peak disp.

Fig.6 Comparison between peak response under bidirectional and unidirectional ground motion

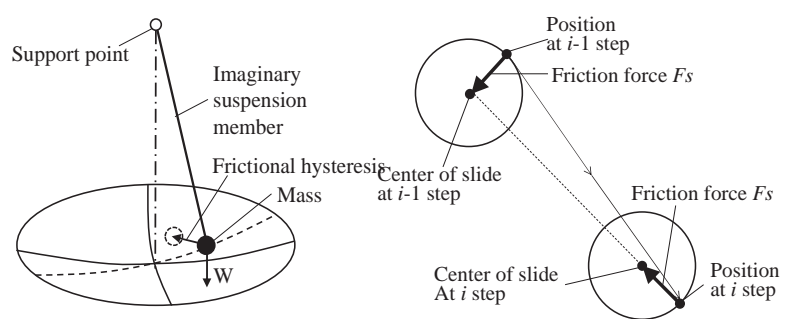

(a) Model configuration

(b) Frictional hysteresis

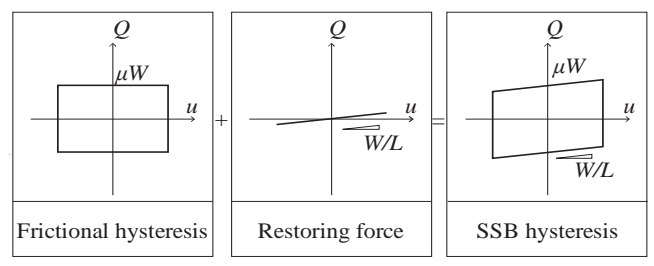

(c) One-way hysteresis

Fig.7 FP analytical model

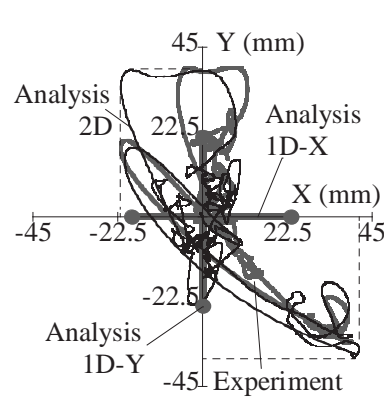

(a) Horizontal disp. orbit

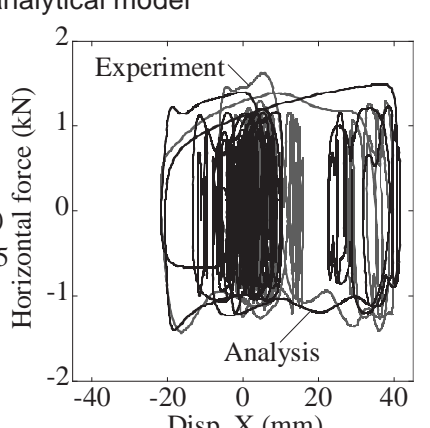

Disp. X $(\mathrm{mm})$
(b) Force-Displacement hysteresis

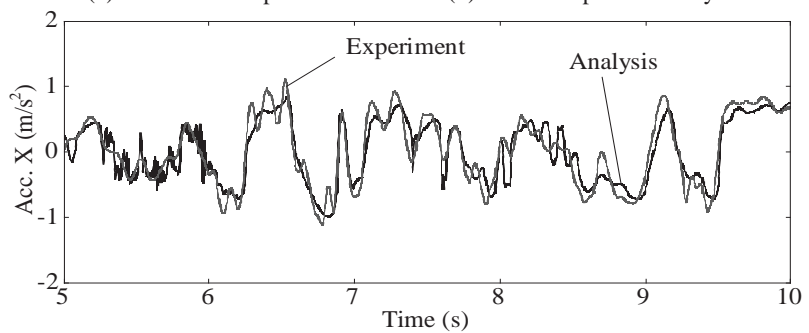

(c) Time history of response acc.

Fig. 8 Comparison between experimental and analytical response (EI Centro-N 2D)

\section{3 水平二方向振動台実験の再現解析}

次にSSB の履歴モデルに, 文献 5)で提案された, 摩擦履歴の二方向 性を考慮した FP モデルを用いた時刻歴応答解析を用いて, 振動 台実験の再現および仮説の検証を行う。Fig.7 にFP モデルの概要を 示す。FP モデルは球面挙動をモデル化する振り子要素と摩擦要素よ り構成されている。振り子要素は固定点より吊り下げられた軸剛性の 高いトラス要素で, 先端に上部構造支持節点が接続されており, 重力 加速度および幾何非線形性を考慮することで二方向の振り子挙動を 模擬する。摩擦要素は上部構造支持節点の水平変位に対し式(2)で示さ れる摩擦力を移動方向に沿って発揮する。除荷時変位は鴨下らの摩擦 モデル 3) を参考に, すべり中心の進行軸線上に求める (Fig.7(b)).

実験再現モデルはSSB の支持重量(1.76t) と同等の重量をもつ質点 を吊材に接続した簡易モデルであり, 実験実測より基準摩擦係数 $\mu_{0}$ を 0.072 とする。入力地震波には振動台に設置した加速度計にて測 定した值を用いる。Fig.8 に水平変位オービット, せん断力一変位関 係, 応答加速度時刻歴を実験值と解析值で比較して示す。いずれの グラフにおいても解析值は実験值を概ね再現しており，二方向入力 
Table2 Summary of mass, stiffness and member size

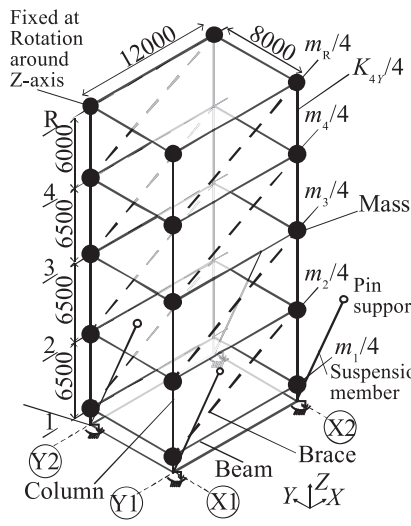

Fig.9 Multistory frames model

\begin{tabular}{|c|c|c|c|}
\hline & $m_{i}$ & $K_{i X}$ & $K_{i Y}$ \\
\cline { 2 - 4 } & $(\mathrm{kN})$ & $(\mathrm{kN} / \mathrm{mm})$ & $(\mathrm{kN} / \mathrm{mm})$ \\
\hline \hline $\mathrm{R}$ & 26.3 & & \\
\hline 4 & 290.6 & 4.4 & 3.68 \\
\hline 3 & 1629.5 & 14.57 & 13.39 \\
\hline 2 & 1232.6 & 40.86 & 35.89 \\
\hline 1 & 1851.8 & 52.28 & 47.99 \\
\hline
\end{tabular}
(b) Member dimension (CHS)

\begin{tabular}{|c|c|c|c|}
\hline & Column & Brace & \multirow{2}{*}{ Beam } \\
\hline $\mathrm{R}$ & & & \\
\cline { 1 - 2 } 4 & $\phi 500 \times 1.7$ & $\phi 50 \times 0.19$ & \multirow{2}{*}{} \\
\cline { 1 - 2 } 3 & $\phi 500 \times 8.0$ & $\phi 50 \times 0.33$ & $\phi 500 \times 35$ \\
\hline 2 & $\phi 500 \times 24$ & $\phi 50 \times 1.4$ & \\
\cline { 1 - 2 } 1 & $\phi 500 \times 34$ & $\phi 50 \times 1.2$ & \\
\hline
\end{tabular}
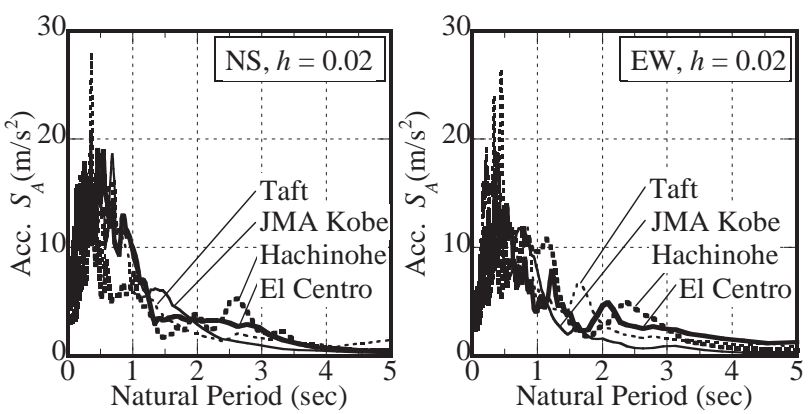

Fig.10 Acceleration response spectrum

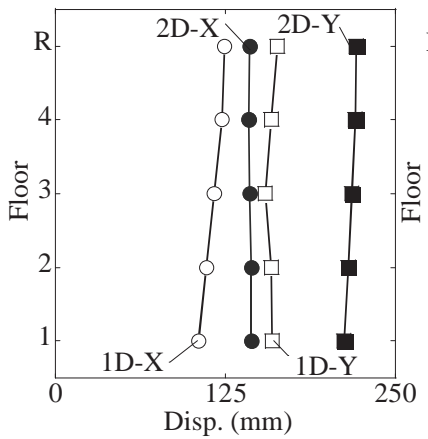

(a) Peak disp.

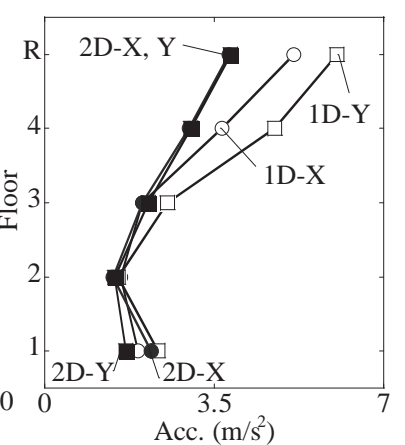

(b) Peak acc.
Fig.11 Peak response of each story (EI Centro)

応答変位は一方向入力応答変位より大きい。他の地震波入力につい ても同等の結果を得ており，二方向入力による応答変位増大の原因 が摩擦履歴の二方向性にあることと, FP モデルが二方向入力におい てSSB の応答を再現していることがわかる。

\section{SSB で支持された重層倉庫の応答特性}

次に, SSB の二方向応答特性が上部構造の応答に与える影響を分 析するため, 4 層の重層倉庫を模擬した立体架構を対象に時刻歷応 答解析を行う。

\section{1 重層倉庫立体架構モデルの設定}

Fig.9 に立体架構モデルを, Table2 に各諸元を示す。上部構造部材 は各節点の回転を拘束し, 想定建物と等価なせん断剛性を有する各 方向 1 スパンモデルとして模擬する。層剛性は相当するせん断剛性 を有する架構およびブレース材を用いて同定する。同等のせん断剛

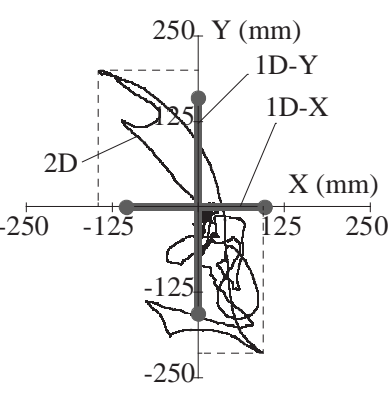

(a) Horizontal disp. orbit (1F)

Fig. 12 Horizontal orbits of multistory frames (EI Centro)

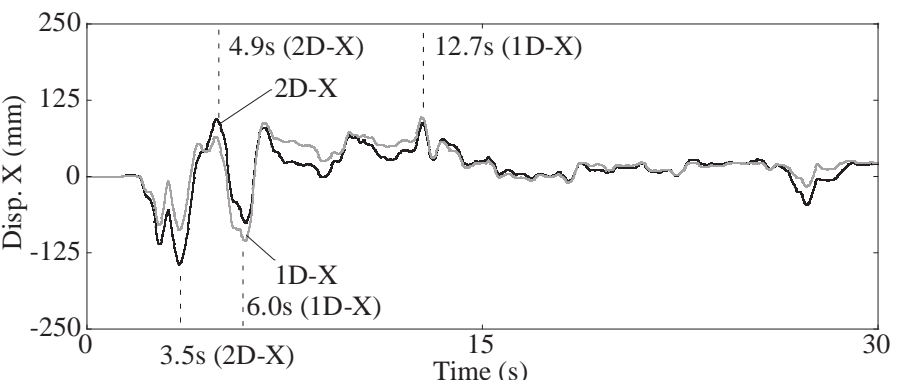

(a) Time history of response disp. (X,1F)

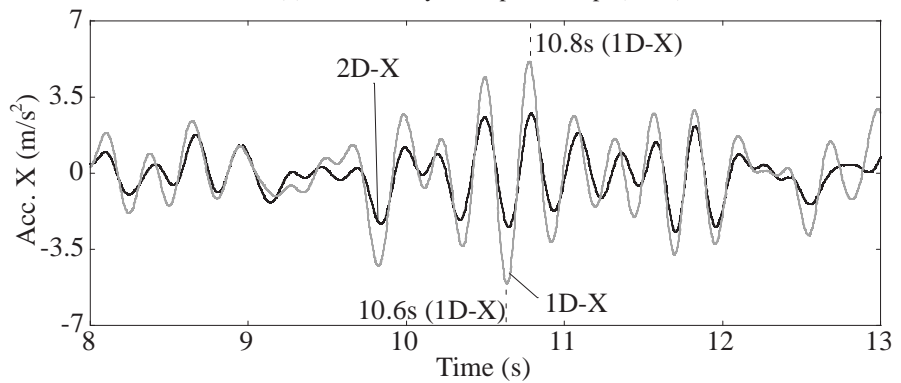

(b) Time history of response acc. (X,RF)

Fig.13 Comparison between bidirectional and unidirectional time histories (EI Centro)

性を有する多質点せん断ばねモデルを用いて固有值解析を行い，両 モデルの固有周期が精度よく一致することを確認している。1 次固 有周期は $X$ 方向 : 0.637s, $Y$ 方向 : 0.671s である。支承部の履歴モデ ルにはFP モデルを用いる。スライダー径 $200 \mathrm{~mm}$ ，限界変形 $450 \mathrm{~mm}$ の支承を想定し, 基準摩擦係数は $\mu_{0}=0.05$, 球面半径は $I=4.5 \mathrm{~m}$ (吊材 長さは L =9m） とする。入力地震波は Fig.10 に示すように, 観測地 震波 4 波それぞれの NS，EW 波のうち一方向について最大速度を $500 \mathrm{~mm} / \mathrm{s}$ に調整して他方向は同比率で合わせ，位相のみならず応答 スペクトルも観測波の方向性を維持する。入力時間は $50 \mathrm{~s}$ とする。 $\mathrm{NS}$ 波を X 方向に, EW 波をY 方向に入力寸る。

\section{2 上部構造の応答特性}

以下, 上部構造および支承部の応答を二方向入力と一方向入力で比 較して示す。Fig.11 に各層の応答変位および応答加速度の最大值を 示す。(a) の応答変位は 2 章で示した実験と同様に二方向入力で方 向入力の值を上回っている。 (b) の応答加速度も実験と同様, 支承 部では入力方向によらず同程度となっている。しかし，上層では二 方向入力で応答増幅の程度が低減している。Fig.12 に $1 F$ の応答変位 およびRF の応答加速度のオービットを示す。(a) の応答変位は実 験と同様，二方向応答の連成により最大值が増幅している。一方， (b) の R 階での応答加速度は二方向入力では減少する傾向にある。 
これは二方向入力下で直交方向の入力が加わることで免震層の履歴 形状の変化により上層部の応答加速度の励起が抑えられたものと考 えられる。Fig.13 に応答変位と応答加速度の時刻歴を示す。(a) の応 答変位は, 最大值を記録する時刻(4.77s)で, 二方向入力の方が大き な応答となっているが，(b) の応答加速度は時刻歴全体に渡って二 方向入力の方が小さな応答振幅となっている。これらの傾向は他の 方向、地震波でも同様となっている。Fig.14 に各階の最大応答変位 および加速度を二入力方向と一方向入力で比較したものを全入力に ついて示す。二方向入力では一方向入力に比心゙，変位は最大で $40 \%$ 程度増幅し, 加速度は最大 $40 \%$ 程度低減している。

以上のように，SSB で支持された立体架構では，二方向入力下で 応答変位の最大值が全層に渡り増大寸る傾向がある一方で, 上層の 応答加速度が一方向入力に比心゙低減する傾向のあることが分かる。

\section{4. 履歴モデルの復元力特性が応答に与える影響}

本章では，SSB の履歴モデルとして用いられる M SS モデルと FP モデルを用いて, 二方向入力下におけるSSB の応答特性を検証する。 Fig.15 に MSS モデルの概念を示す。本研究では 8 本のせん断ばねを 等角度で配し二方向せん断力の相互作用を考慮できるが, FP モデル と摩擦履歴の構成が異なり, 振り子運動および軸力変動による摩擦 力，速度の変化には対応していない。MSS モデルで SSB を同定す

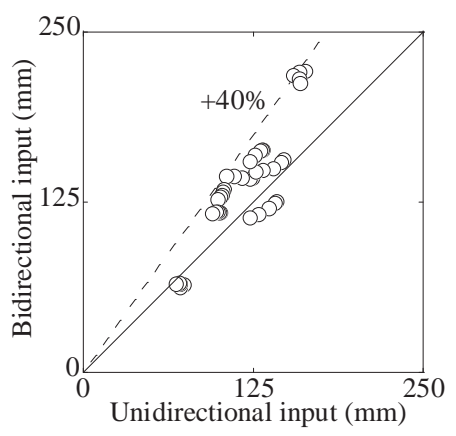

(a) Peak disp.

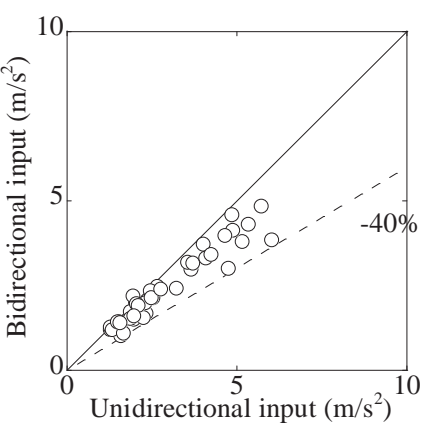

(b) Peak acc.

Fig.14 Comparison between peak response to bidirectional and unidirectional of each story (All ground motions)
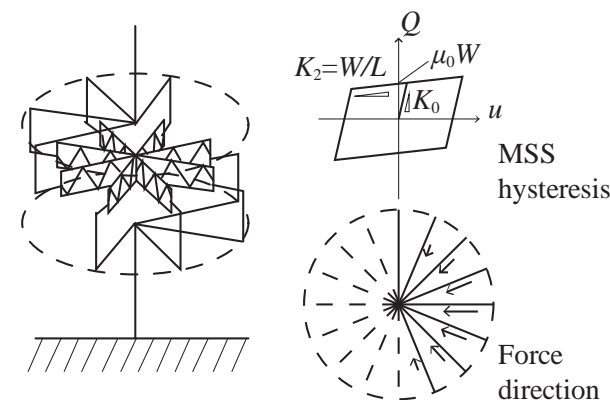

Fig.15 MSS analyticaT model

300 $\mathrm{Y}(\mathrm{mm})$

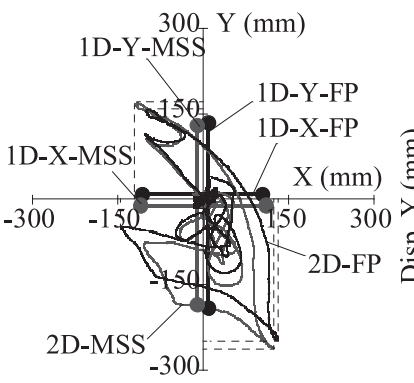

(a-1) Horizontal disp. orbit (L5) 300 Y (mm)

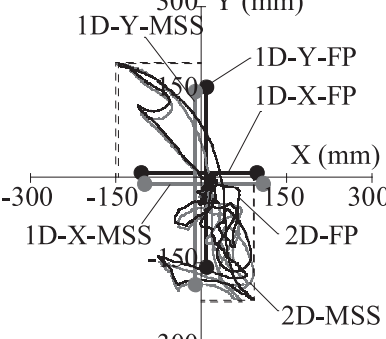

$-300$

(a-2) Horizontal disp. orbit (L9) 300 Y $(\mathrm{mm})$

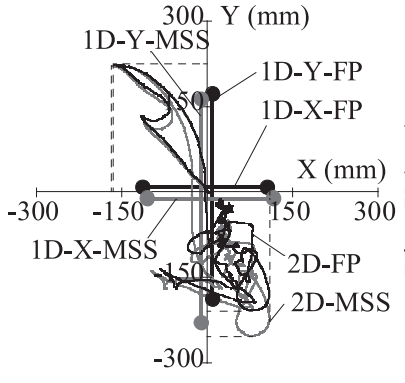

(a-3) Horizontal disp. orbit (L15)

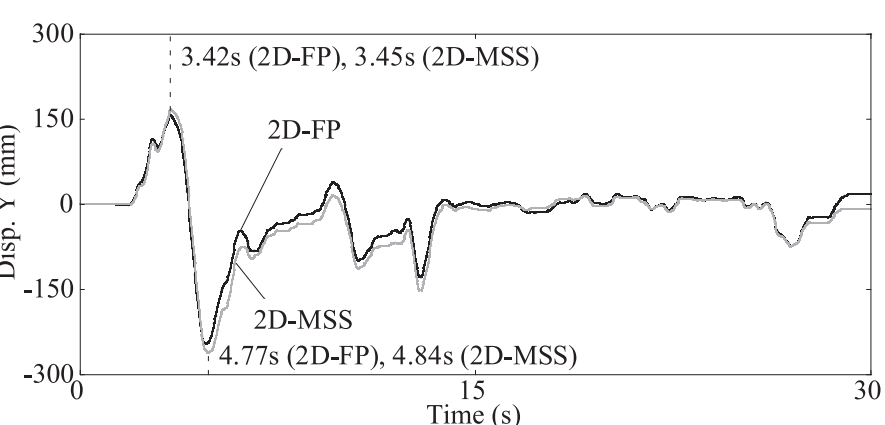

(b-1) Time history of response disp. (L5, Y)

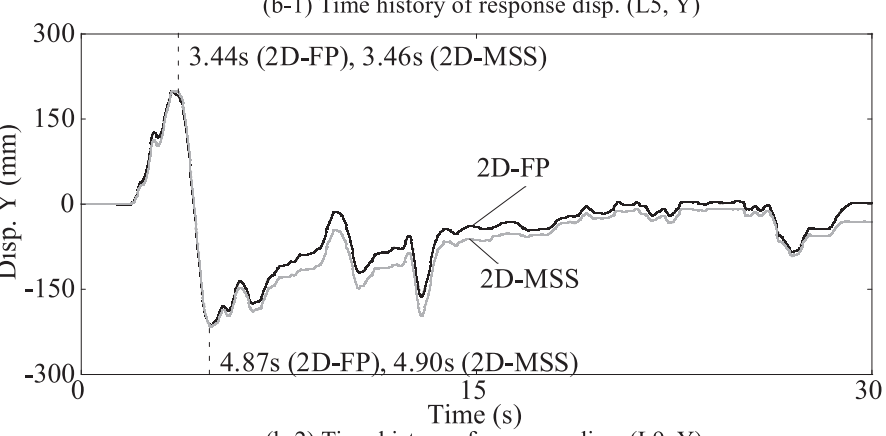

(b-2) Time history of response disp. (L9, Y)

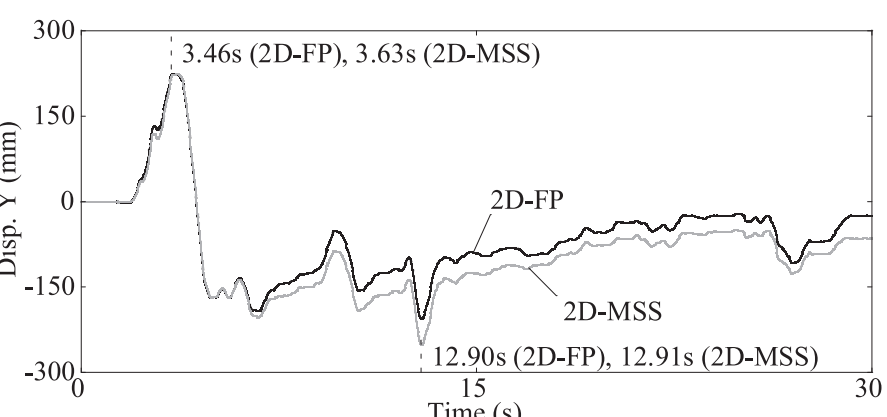

Time (s)
(b-3) Time history of response disp. (L15, Y)
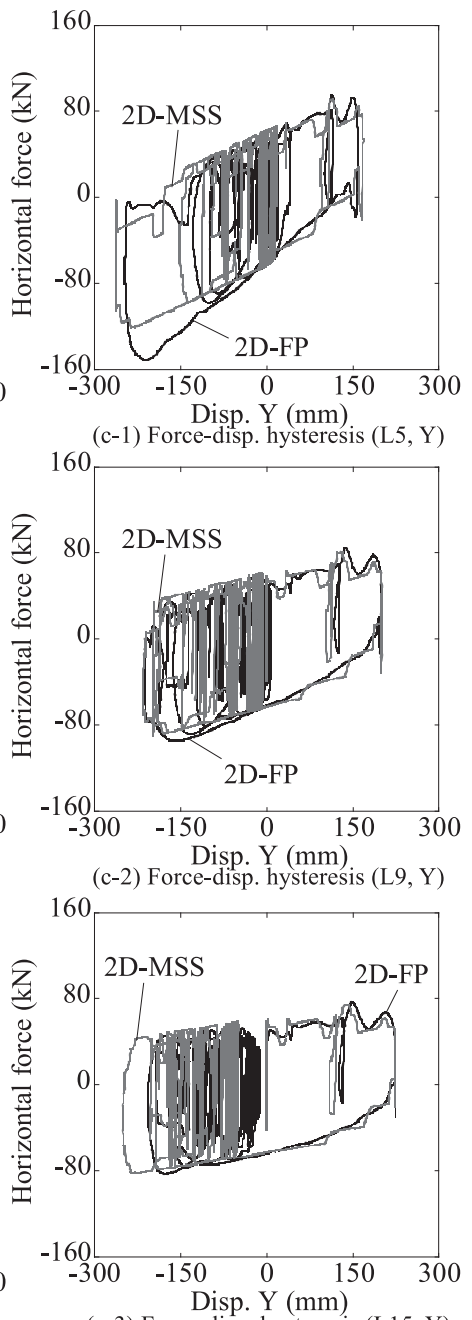

(c-3) Force-disp. hysteresis (L15, Y)

Fig. 16 Comparison between FP and MSS model in the state of various spherical radii (4 story build., El Centro, L5, 9, 15) 


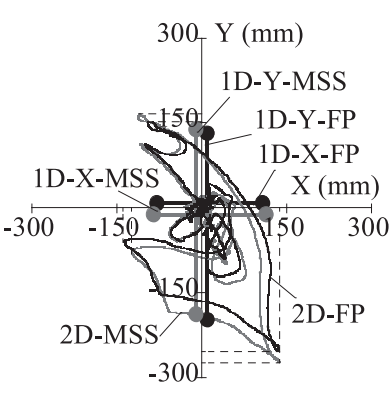

(a) Horizontal disp. orbit

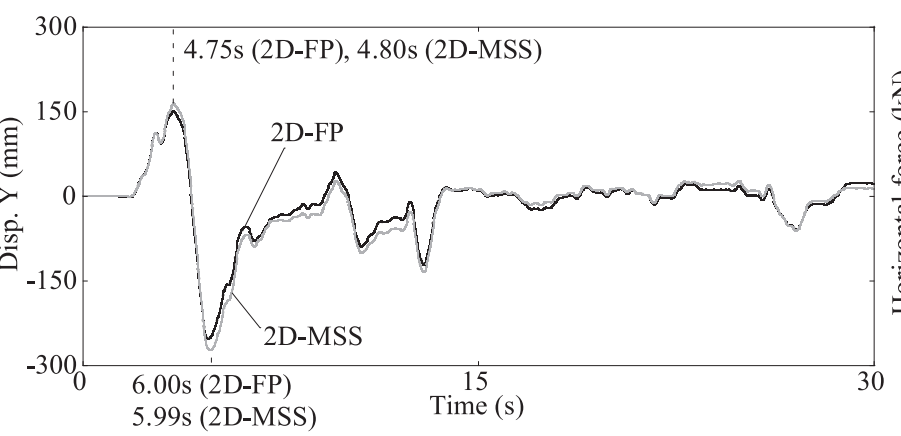

(b) Time history of response disp. (Y)

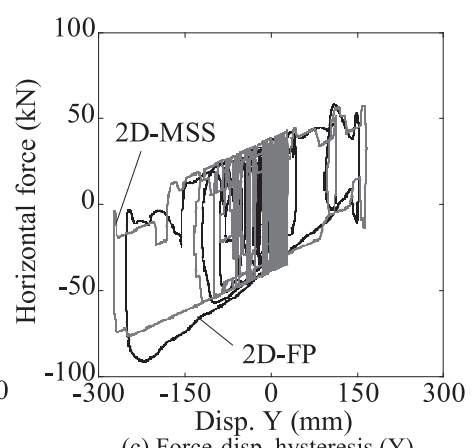

(c) Force-disp. hysteresis (Y)

Fig. 17 Comparison between FP and MSS model (1 story build., El Centro, L5)

る場合, ばねの降伏耐力 $Q_{y}$ と一次剛性 $K_{0}$ および二次剛性 $K_{2}$ はそれ ぞれ式 (4)，(5) により定める。
$Q_{y}=\mu_{0} W$
(4)
$\left\{\begin{array}{l}\mathrm{K}_{0}=1000 \mathrm{~K}_{2} \\ \mathrm{~K}_{2}=\mathrm{W} / \mathrm{L}\end{array}\right.$

FP，MSS の両モデルを整理すると，(1)F モデルは振り子運動によ る鉛直変位を表現しているが, MSS モデルは水平変位のみである, (2)FP モデルはすべり判定時全方向に摩擦履歴の剛性が消失するが, MSS モデルは変位方向に直交するばねが必ずしも降伏しない。従っ て FP モデルは変位方向に作用する摩擦力と部材原点方向に作用す る振り子運動による復元力を合成してせん断力とするが, M SS モデ ルは部材原点方向に作用する各ばねの合力がせん断力となる, (3FP モデルでは今回使用の MSS モデルに対し支承部鉛直面圧および速 度の変動による摩擦係数の変化を考慮している，という３点で異な る。なお，速度依存の影響に関してはＭSS モデルに組み込むことも 可能である。(2)の影響はSSB の二次剛性が低いほど顕著となると考 えられるため球面半径が, (3)にはSSB の振り子運動および上部構造 の転倒モーメントすなわち塔状比が影響すると考えられる。そこで, 球面半径と上部構造を変化させ両モデルによる支承部応答の変化を 検証することで, 前記(2)(3)の要因が応答に与える影響を分析する。

\section{1 上部構造と各履歴モデルの設定}

上部構造はFig.9 で示した 4 層立体架構モデルと, その 1 層目の みの 1 層立体架構モデルとする。部材諸元は Table2 と同様である。 SSB は $\mu_{0}=0.05$, 球面半径は I $=2.5,4.5,7.5 \mathrm{~m}$ とし, それぞれ吊材長さ より L5, 9, 15 モデルと呼ぶ。スライダー径は上部構造の固定荷重入 力時の支承部鉛直荷重に対して面圧が $60 \mathrm{~N} / \mathrm{mm}^{2}$ となるよう定める。

\section{2 復元力計算が応答に与える影響}

まず(2)の影響について，4 層立体架構に対し球面半径の異なる 3 種のSSB を用いて両履歴モデルでの応答を比較する。Fig.16に各球 面半径での支承部の水平変位オービット，応答変位時刻歴およびせ 几断力ー変位関係を示す。(a-1), (a-2), (a-3) より, MSS モデルでも 二方向入力で最大応答值が一方向入力より大きくなる傾向が捉えら れていることが分かる。これは，MSS モデルでも二方向入力におけ る履歴ループの変動が模擬されていることによる。(a-2)では両モデ ルのオービットは近い形状を示すが，(a-1), (a-3) では最大変位など で差異がみられる。球面半径の小さい(b-1)を見ると, 変位が最大 となる初動期の 4.85 付近でFP と M SS の差異が生じているのに対し, 球面半径が増加する(b-2), (b-3) に移行するにつれ, 定常振動時の緩 やかに変位する $12.9 \mathrm{~s}$ 付近での差が大きくなっていることが
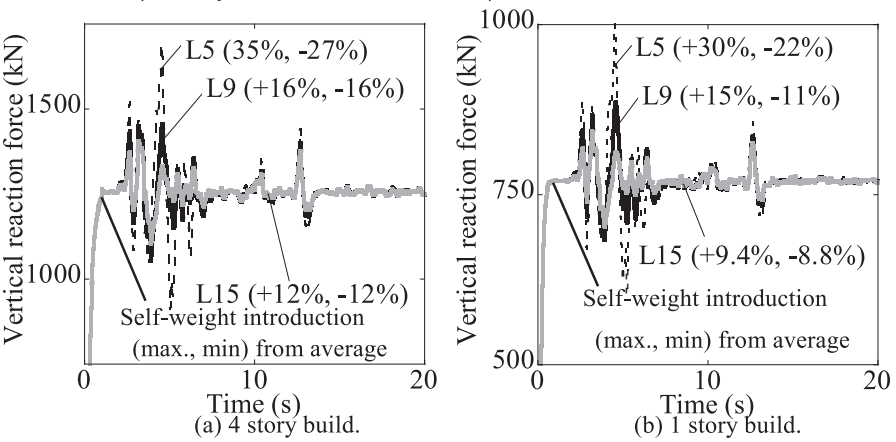

Fig.18 Vertical reaction force (El Centro)

分かる。また, 最大せん断力については (c-1) においてのみ初動時 に両モデルで $30 \%$ 程度の顕著な差が生じているが, それ以外の場合 の履歴はFPと MSS で概水同形状となっている。

以上より, SSB の二方向応答について M SS モデルと FP モデルを 比較すると, 球面半径が大きくなるほど(2)の違いに起因する変形へ の影響が顕著となる一方, 球面半径が小さい場合においては, 変形 のみならず初動時の最大せん断力の差異が生じており, (3)の鉛直振 動による摩擦力の差が影響していると考えられる。

\section{3 軸力変動が応答に与える影響}

そこで(3)の影響について，4層（アスペクト比 3.2）と 1 層（アス ペクト比 0.8）立体架構による応答を比較しながら軸力変動の影響 を比較する。Fig.17 に Fig.16 と同様のグラフを L 5 モデルについて 示す。(a) を見ると，4 層モデルに比べて両履歴モデルのオービッ トはより近い形状になっているが，最大值などで差異が生じる傾向 は変わらない。 (b) の時刻歴および(c) の履歴ループは 4 層モデル の場合と同様, 初動時のせん断力に最大 $30 \%$ 程度の差異が生じてお り，1 層モデルにおいても支承部鉛直荷重の変動が大きくなってい るものと考えられる。そこで, Fig.18 にFP モデルでの吊材軸力より 評価した支承部鉛直荷重平均值の時刻歴を，4層と 1 層それぞれにつ いて示す。 4 層, 1 層ともに球面半径に応じて初期軸力に対する軸力 変動幅は最大で $\pm 10-30 \%$ 程度になっており, 主に振り子運動による上 下動に起因して軸力変動が生じていることがわかる。なお，このほか の入力についても, 軸力変動幅は最大水平変形量が大きいほど大きく なることを確認している。付録 2 として，4 層モデルにおける各支持 点の鉛直加速度時刻歴, 鉛直反力時刻歴および变位オービットを示す が, 転倒モーメントによる各支持点の反力変動は微小であり, 鉛直加 速度および変位オービットは各支持点で同等となっている。

以上を総合すると, 検討範囲では上部構造および支持点に依らず 支承部鉛直荷重が変動しており，上部構造の塔状比に影響を受ける 
転倒モーメントよりも振り子運動の影響が支配的となっていると考 えられる。このため, SSB の球面半径が小さいほど振り子運動の影 響が大きくなり，球面半径の違いによる鉛直荷重の変動が顕著に現 れるものと考えられる。

ここまで示した MSS モデルと FP モデルの応答比較から, 球面半 径が大きい場合には(2)の影響を受けて応答変位などに差異が生じ, 球面半径が小さい場合には上部構造が低層の場合でも支承部鉛直荷 重変動が大きくなり，(3)の影響により応答せん断力や応答変位に差 異が生じることが分かった。そのためSSB を用いる場合は上部構造 やSSB の球面半径に依らず, FP モデルなどの鉛直荷重変動や (2) 振り子運動（1) を再現した履歴モデルを用いて応答検証を行うの が望ましいと言える。

\section{5. 結}

本研究では, SSB の水平二方向応答特性を検証するため振動台実 験を行うと共に，上部構造に与える影響を時刻歴応答解析により示 した。また, 実設計を考慮して, 振り子挙動等を模擬した FP モデ ルと MSS モデルの相違点を検証し，一方向入力により二方向応答を 考慮した応答検証例を示した。以下に得られた知見を示す。

1) 検討した地震波の範囲において支承部の二方向入力応答はその 直交方向成分としての一方向入力応答に比べ, 变位が最大 2 倍 程度に増大寸る。一方, 加速度は土15\%程度にばらつくが概ね各 方向の独立性を保つ。FP モデルはこれらの二方向応答特性を再 現できることが確認された。

2) SSB で支持された構造物について，一方向入力下で上層部での 応答加速度が増幅する場合でも，二方向入力下で直交方向の入 力が加わることで履歴形状の変化により応答加速度が低減する ことが多い。一方，支承部の変位は増大寸る傾向がある。

3） MSS モデルと FP モデルでは二方向入力において，SSB の球面 半径が大きい場合には摩擦履歴のモデル化の差により応答変位 などに差異が生じやすい。一方，球面半径が小さい場合には振 り子運動による鉛直荷重変動幅が大きくなり，上部構造のアス ペクト比 0.8 3.2 程度の範囲では上部構造によらず両履歴モデ ルの応答変位，反力值に差異が生じる。

4）前述 1）-3）から, 摩擦履歴の二方向特性と振り子運動を考慮し た FP モデルはこれらを考慮しないMSS モデルに比べ，二方向 入力下の SSB の応答をより良好に再現できると考えられる。

\section{謝辞}

本研究は科学研究費 (基盤研究 (B) N 015H 04075, 鉄骨置き屋根 構造の地震被害解消を目的とした応答制御型支承の研究，研究者代 表 : 竹内徹) のもとで実施された。実験にあたっては株式会社中村 構造研究所：中村秀司氏，新日鉄住金エンジニアリング：長谷川久 巳氏，株式会社ダイナミックデザイン：宮㠃光生氏のご助力，ご助 言を頂いた。ここに深謝したい。

\section{参考文献}

1) M inewaki, S., Y amamoto, M ., Higashino, M ., Hamaguchi, H., K yuke, H., Sone, T., Y oneda, H. and Wada, A.: Performance Tests of Full Size Isolators for Super High-Rise Isolated B uildings, J ournal of structural engineering, V ol. 55B, pp.469-477. 2009.3 (in Japanese)
嶺脇重雄, 山本雅史，東野雅彦，浜口弘樹，久家英夫，曾根孝行，米田 春美，和田章：超高層免震建物の地震応答を想定した実大免震支承部材 の性能確認試験，構造工学論文集，Vol.55B，pp.469-477，2009.3

2) Kikuchi, M., Y amamoto, M., Ishii, K. and Sasaki, Y.:Horizontal Bidirectional Hysteresis Properties of L ow-modulus High-dumping Rubber B earings, J ournal of Structural and Construction Engineering (Transactions of AlJ), V ol. 79, No. 696, pp.257-265, 2014.2 (in J apanese)

菊地優, 山本雅史, 石井建, 佐々木頼孝: 低弾性高減衰積層ゴムの水平 2 方向復元力特性に関寸る研究, 日本建築学会構造系論文集, 第 79 巻, 第 696 号, pp.257-265, 2014.2

3) Kamoshita, N., Yamamoto, M., Minewaki, S., Kikuchi, M., Ishii, K., Kouchiyama, $\mathrm{O}$. and Nakamura, T.: Horizontal Bidirectional Characteristics of Elastic Sliding B earings under V arious Fluctuant V ertical L oading Conditions, J ournal of Structural and Construction Engineering (Transactions of AlJ), $\mathrm{V}$ ol. 79, N o. 698, pp.453-461, 2014.4 (in J apanese)

鴨下直登，山本雅史，嶺脇重雄，菊地勝，石井建，河内山修，仲村崇仁： 数種の面圧条件下における弾性すべり支承の水平二方向特性, 日本建築 学会構造系論文集, 第 79 巻, 第 698 号, pp.453-461, 2014.4

4) Samejima, Y., Kikuchi, T., K ato, H. and other 2: Earthquake Simulator Testing of High-Damping Rubber Bearing Focused on Bi-Lateral Force-Displacement Characteristics, Part1, 2, Summaries of Technical Papers of Annual Meeting A rchitectural Institute of J apan, Structures-II, pp.269-272, 2010.9 (in J apanese) 鮫島祐介，菊池隆志，加藤秀章：高減衰ゴム系積層ゴムの振動台実験に よる二方向入力時の応答性状, その 1, 2, 日本建築学会大会学術講演梗 概集，構造 II，pp.269-272，2010.9

5) Fukui, Y., Hotta, H.,: Bi-directional Seismic Response of Base-isolated Layer with Layered Rubber Support containing Lead Plug, Proc. Summaries of Technical Papers of Annual Meeting Architectural Institute of Japan, Structures-II, pp.565-566, 2016.8

福井淑子、堀田久人 : 鉛プラグ型積層ゴム支承を用いた免震層の 2 方向 地震応答に関する研究、日本建築学会大会学術講演梗概集、構造 II, pp.565-566, 2016.8

6) Takeuchi, T., Nakamura, H., U chida, M., Y oshida, M . and M atsui, R.:Shaking Table Tests on Spherical Sliding Bearings Taking Eccentricity and U plift into A count, Journal of Structural and Construction Engineering (Transactions of AlJ), Vol. 80, N o. 715, pp.1385-1392, 2015.9 (in Japanese)

竹内徹, 中村秀司, 内田正颯, 吉田道保, 松井良太 : 偏心および浮き上 がりを考慮した球面すべり支承の振動台実験, 日本建築学会構造系論文 集，第 80 巻，第 715 号, pp.1385-1392, 2015.9

7) Takeuchi, T., Y oshida, M ., Uchida, M ., N ishi, O. and M atsui, R.:A pplication of Seismic Isolation Bearings for Rack Warehouse to Prevent Goods Falling, J ournal of Structural and Construction Engineering (Transactions of $\mathrm{AlJ}$ ), $\mathrm{Vol}$. 81, No. 721, pp.629-637, 2016.3 (in J apanese)

竹内徹，吉田道保，内田正颯，西雄士，松井良太 : 積載物の落下防止を目 的とした立体倉庫への免震支承の適用, 日本建築学会構造系論文集, 第 81 巻, 第 721 号, pp.629-637, 2016.3, (DOI http://doi.org/10.3130/aijs.81.629)

8) Takeuchi, T., M iyazaki, T. and Ogawa, T.: Seismic Response Evaluation of Cylindrical Lattice Shell Roofs Supported by Spherical Sliding Bearings, J ournal of Structural and Construction Engineering (Transactions of $\mathrm{AlJ}$ ), $\mathrm{Vol}$. 81, No. 728, pp.1673-1682, 2016.10 (in J apanese)

竹内徹, 宮﨑崇, 小河利行 : 球面すべり支承で支持された屋根型円筒ラ チスシェルの地震応答評価, 日本建築学会構造系論文集, 第 80 巻, 第 728 号, pp.1673-1682, 2016.10, (DOI http://doi.org/10.3130/aijs.81.1673)

9) Wada, A. and Kinoshita, M.:Elastic Plastic Dynamic 3-Dimensional Response A nalysis by using a Multiple Shear Spring Model, Part1, 2, Summaries of Technical Papers of A nnual M eeting A rchitectural Institute of J apan, Structures II, pp.313-316, 1985.10 (in Japanese)

和田章, 木下雅彦: M SS モデルを用いた柱降伏型の建物の立体振動解析, その 1, 2, 日本建築学会大会学術講演梗概集, 構造 II, pp.313-316, 1985.10

10) Nakamura, H., Nishimoto, K. and Tomimoto, A.: Development of Spherical Sliding Bearing, Nippon Steel \& Sumikin Engineering Co., Ltd. Technical Review, Vol.6, pp.28-35, 2015 (in J apanese)

中村秀司，西本晃治，富本淳：球面寸心゙り支承 NS-SSBR の開発，新日鉄 住金エンジニアリング技法, Vol. 6, pp.28-35, 2015

11) Building Research Institute, Japan Building Center: Recommendations for Method Calculating the Waves in the Time Domain for Structural Design, , pp.24, 1992.3 (in Japanese)

建設省建築研究所, 日本建築センター：設計用地震動作成手法技術指針 (案), pp.24, 1992.3 
付録 1

Fig. 8 にて比較しているFP モデルと実験結果の加速度応答最大值の比較を Fig.A1 に示す。地震波により多少のばらつきが見られるものの、両者は概ね $\pm 20 \%$ 程度の精度で対応していることが分かる。

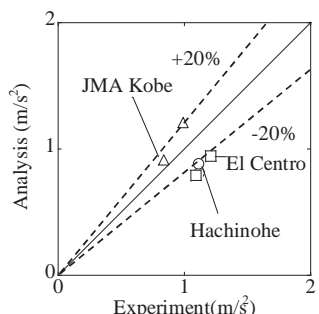

(a) NS Direction

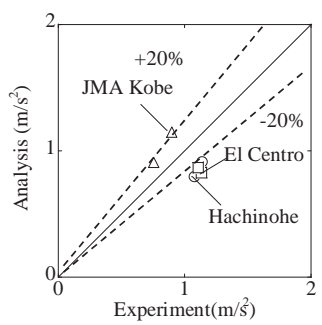

(b) EW Direction
Fig. Al Comparison between peak response under
付録 2

4 章においては, 支承部の鉛直反力変動の要因が転倒モーメントではなく, 主に球面すべり面の振り子運動に起因するものと推察した。4 層モデル L5 $の$ ケースにおいて, 各支承部における鉛直応答加速度, 鉛直反力の時刻歴, お よび変形オービットをFig. A 2 に示す。なお，支承部反力には振り子要素の軸 力を用いており，その鉛直成分との差は $0.2 \%$ 以下である。(b),(c)の鉛直応答 加速度に関しては，各節点ともほぼ一致して変動している。一方，(d),(e)の 支持点反力に関しては隣り合う支持点で位相の反転が見られるが，その差は 極めて微小で $20 \mathrm{kN}$ 程に留まっている。(f),(g)のオービットは各支承部ともほ ぼ同じ軌跡を描いている。以上より 4 層モデルにおいても, 球面すべり支承 を用いた場合の転倒モーメントが鉛直加速度に与える影響は非常に小さく, 支承部の鉛直反力変動の要因は転倒モーメントではなく, 主に球面す心゙り面 の振り子運動に起因するものと考えられる。

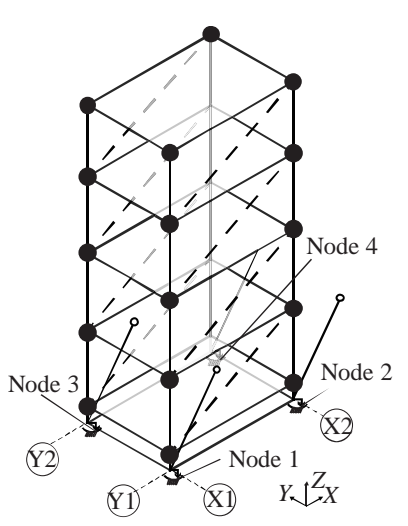

(a) Node and member designation
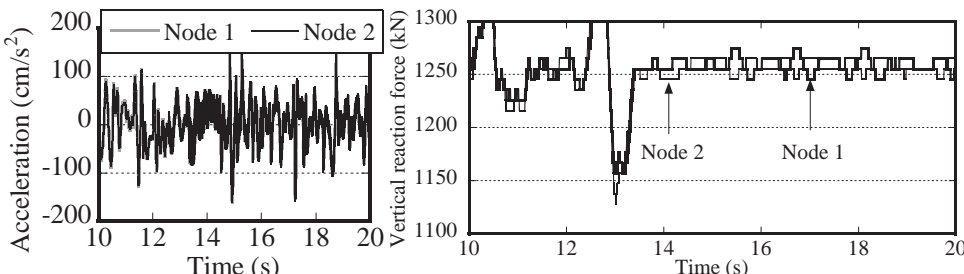

(b) Acc. at Node 1 and 2 (10 - 20s)

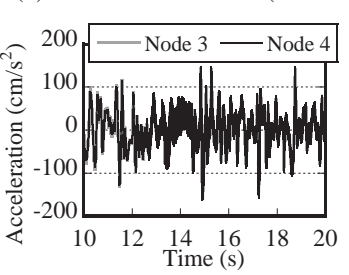

(c) Acc. at Node 3 and $4(10-20 \mathrm{~s})$

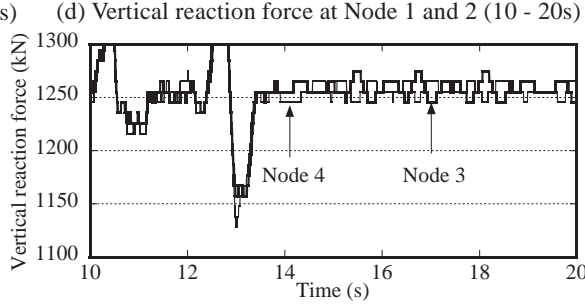

(e) Vertical reaction force at N ode 3 and 4 (10 - 20s)

Fig. A2 Acceleration response and displacement (Bi-directional input, L5, EI Centro)

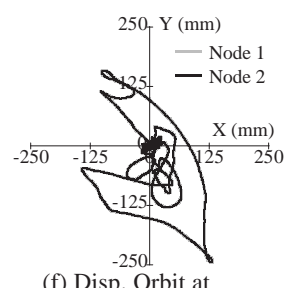

(f) Disp. Orbit at Node 1 and 2 (0 - 50s)

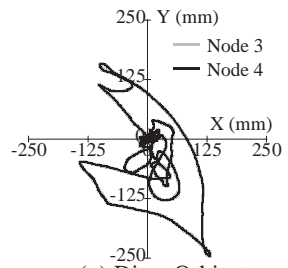

(g) Disp. Orbit at Node 3 and 4 ( 0 - 50s) 


\title{
RESPONSE CHARACTERISTICS OF SPHERICAL SLIDING BEARINGS AND SUPERSTRUCTURE SUBJECT TO BIDIRECTIONAL GROUND MOTIONS
}

\author{
Toru TAKEUCHI ${ }^{* 1}$, Masakaze UCHIDA ${ }^{* 2}$ and Ryota MATSUI ${ }^{* 3}$ \\ ${ }^{* 1}$ Prof., Dept. of Arch. and Build. Eng., Tokyo Institute of Technology, Dr. Eng. \\ ${ }^{* 2}$ Former Grad. Student, Dept. of Arch. and Build. Eng., Tokyo Institute of Technology, M. Eng. \\ ${ }^{* 3}$ Assist. Prof., Dept. of Arch. and Build. Eng., Tokyo Institute of Technology, Dr. Eng.
}

\section{Introduction}

Although the performance of seismic isolation devices such as rubber bearings or dampers have been tested and evaluated through unidirectional input, in fact these devices are subjected to seismic ground motions in two direction. Recently the performance of high-damping rubber bearings under bidirectional input is found to be different from that under unidirectional input, and bidirectional tests for various isolation devices are being carried out. In this paper, bidirectional shaking table tests for SSB (Spherical Sliding B earing ( Friction Pendulum Bearing: FPB) are conducted, and the difference of their response against unidirectional response are investigated. Bidirectional effects are discussed using analytical model taking these testing results into account, followed by the studies on the effects on the response of supported superstructures.

\section{Bidirectional shaking table tests for a single SSB}

Bidirectional shaking table tests for a single SSB are carried out. A mass gives dead load $24.3 \mathrm{~N} / \mathrm{mm}^{2}$ pressure on a sliding bearing surface of the SSB, expected friction coefficient is calculated as 0.056 , and natural period after slipping is $4.5 \mathrm{sec}$. As a result, the maximum response displacement of the SSB under bidirectional input is larger than that under unidirectional input, and acceleration is same level between both inputs. These differences are considered to be caused by the bidirectional effects of friction force vector.

\section{Response of multistory frames supported by SSB under bidirectional input}

The response obtained by the shaking table tests is compared with numerical analytical results with a friction pendulum model (FP model) which taking account of pendulum action and bidirectional effects of friction force vector proposed by the authors. The FP model well explains the difference of response under bidirectional vs. unidirectional input. The response of multistory frames supported by the SSB is also studied, and excitation in the displacement response and reduction in the acceleration response are observed.

\section{The effects of hysteretic models on the bidirectional response}

In this chapter, the bidirectional response effects of the FP model and ordinary MSS model (M ultiple Shear Spring) which does not simulate pendulum action and has different bidirectional effects of friction force vector are discussed. As a result, the bidirectional effects of friction force vector are significant during the post-sliding frictional stiffness decreasing. Also the effects of normal reaction forces are remarkable, which are not caused by the overturning response of the superstructure, but mostly by the pendulum actions.

\section{Conclusions}

1) The maximum displacement response under bidirectional input generally becomes larger than that under unidirectional input, while acceleration response generally keeps independency between unidirectional and bidirectional input. These bidirectional response characteristics of the SSB are well explained with the FP model.

2) In multistory frames supported by the SSB, displacement response increases in each story while acceleration response in the upper story decreases by additional bidirectional input compared with unidirectional input.

3) Using a SSB with large spherical radius, the response by the MSS model differs from that by FP model. That is mainly because MSS model has different bidirectional effects of frictional force vector. $\mathrm{O} n$ the other hand, the effects of nominal reaction forces become remarkable in the case of using SSB with small spherical radius, which is mainly caused by pendulum action.

4) The proposed FP model including the pendulum action is considered to be more suitable for evaluate the response characteristics of SSB discussed above than M SS model. 